Japan. J. Med. Sci. Biol., 23, 249-254, 1970

\title{
NOTES
}

\section{DYSENTERY PRODUCED BY ORAL ADMINISTRATION OF THE COLONIC CONTENTS OF CYNOMOLGUS MONKEYS INFECTED WITH SHIGELLA FLEXNERI 2a}

Our previous studies (Honjo et al., 1964, 1967, 1968 ; Ogawa et al., 1964, 1967 ; Takasaka et al., 1967) have shown that clinically pronounced dysentery was developed in about 60 per cent of cynomolgus monkeys orally administered with $10^{9}-10^{10}$ of a freshly isolated Shigella flexneri 2a. However, it seems unlikely that such a large amount as $10^{9}-10^{10}$ bacilli is ingested at one time to produce clinical manifestation of naturally occurring shigellosis in monkeys. Actually, the oral administration with $10^{6}$ bacilli could not evoke clinically detectable signs of shigellosis (Takasaka et al., 1967). On the other hand, relatively small doses such as $10^{5}$ bacilli directly injected into the cecal lumen could produce dysentery (Takasaka et al., 1968). Recently, Honjo et al. (1969) have demonstrated that the ascorbic acid deficient monkey has, more or less, a lowered resistance, showing the development of dysentery with a relatively small doses of $S$. flexneri $2 \mathrm{a}$ in an oral experimental infection system. To ascertain more relevantly the mode of infection in naturally occurring bacillary dysentery, we have conducted the present oral infection experiment under such a condition that the experimentally administered material may have some characteristics more similar to the naturally infecting agent than the cultivated Shigella used in the previous experiments.

Cynomolgus monkeys (Macaca irus) from the Philippines and Cambodia weighing from 1.8 to $3.5 \mathrm{~kg}$ were used. They were conditioned at our animal room for at least 5 weeks or more prior to use. During the conditioning period, stool specimens of each monkey were tested for the presence of Shigella bacilli 2 to 8 times with negative results, except that $S$. dysenteriae 2 and $S$. sonnei were isolated from 3 monkeys 2 days before or on the day of the administration.

Virulent $S$. flexneri 2a strain 5503 (Ogawa et al., 1966) was used in this experiment.

As the 1st step of this experiment, $10^{9}-10^{10}$ bacilli grown on nutrient agar plates at $37 \mathrm{C}$ for $18 \mathrm{hr}$ were administered into the stomach of 12 starved monkeys by the same method as described previously (Honjo et al., 1964), resulting in the development of pronounced clinical dysentery in 8 of the 12 infected monkeys within 2 days after the challenge. Then, 5 of 8 dysenteric animals were sacrificed 2 days after the challenge when they excreted typical dysenteric diarrhea and the contents of the colon were collected and homogenized with sterile sand glass in a sterile mortar. Various amounts of the homogenized dysenteric contents were suspended in sterile saline or distilled water and the volume of suspension was adjusted to $10 \mathrm{ml}$.

As the 2nd step, these suspensions were immediately administered by the 
Table 1. The amount of dysenteric contents of the colon administered,

\begin{tabular}{cccc}
\hline Group & $\begin{array}{c}\text { Amount of } \\
\text { dysenteric content of } \\
\text { the colon given }\end{array}$ & $\begin{array}{c}\text { No. of viable } \\
\text { fiexneri 2a in } \\
\text { dysenteric content of } \\
\text { the colon given }\end{array}$ & $\begin{array}{c}\text { No. of } \\
\text { animals used }\end{array}$ \\
\hline 1 & $1000 \mathrm{mg}$ & $10^{7.4}-10^{9.0}$ & 12 \\
2 & $1-10 \mathrm{mg}$ & $10^{4.8}-10^{7.0}$ & 16 \\
3 & $0.1 \mathrm{mg}$ & $10^{3.2}-10^{5.0}$ & 16 \\
4 & $0.001 \mathrm{mg}$ & ca. $10^{1}$ & 4 \\
\hline
\end{tabular}

* Titers are expressed by the logarithm to the base of 2 of the endpoint serum dilution.

In the calculation of averages, titers lower than $2^{2}$ were scored as $2^{1}$.

oral route into the stomach of 48 monkeys, that had been starved for about 24 $\mathrm{hr}$ prior to the administration. As shown in Table 1 , group 1 was administered with $1000 \mathrm{mg}$ of the dysenteric contents having about $10^{7}-10^{9}$ viable $S$. flexneri $2 \mathrm{a}$, while groups 2, 3 and 4 were administered with $1-10 \mathrm{mg}$ (viable $S$. flexneri 2a: about $10^{4}-10^{7}$ ), $0.1 \mathrm{mg}$ (viable $S$. flexneri $2 \mathrm{a}$ : about $10^{3}-10^{5}$ ) and $0.001 \mathrm{mg}$ (viable S. flexneri 2a: about $\left.10^{1}\right)$, respectively. The challenged monkeys were observed for whether or not dysentery symptoms developed during the experimental period of 21 days.

Bacteriological procedures for isolation and identification of Shigella in stool specimens were the same as described previously (Honjo et al., 1964).

Serum agglutination titers against $S$. flexneri 2a were determined by the bacterial agglutination test (Honjo et al., 1967).

Microscopic observation of the lesion and detection of Shigella in gastrointestinal tissue were carried out by the routine histological method and by the fluorescent antibody technique described previously (Ogawa et al., 1964).

As shown in Table 1,3 of 12 monkeys in group 1 began to excrete a large quantity of bloody mucous stool 2,3 and 4 days after the administration (3 days on the average in the 3 cases). In one dysenteric case that began to excrete dysenteric diarrhea after 3 days, diarrhea continued for 3 days until the monkey died. Four of 16 monkeys in group 2 developed dysentery after 4 or 5 days (4.3 days on the average). In 3 of 16 monkeys in group 3, bloody mucous diarrhea appeared after 4 or 9 days (7.3 days on the average). One of these 3 dysentery-infected monkeys suffered from especially serious diarrhea and died 2 days after the onset of clear clinical symptoms. On the other hand, all of the 4 monkeys in group 4 administered with $0.001 \mathrm{mg}$ of dysenteric contents were free of dysentery symptoms during the observation period of 21 days.

In all the dysenteric cases of groups 1,2 and 3 , the number of $S$. flexneri 2a per gram of the stool ranged from $10^{7}$ to $10^{9}$, showing almost the same tendency as the stool of monkeys infected orally with a freshly isolated S. flexneri 2a strain in the previous studies (Honjo et al., 1964; Takasaka et al., 1967). Upon bacteriological examinations of the rectal swab, 8 of 11 monkeys $(72.7 \%)$ in group 1,9 of 16 monkeys $(56.3 \%)$ in group 2 and 3 of 15 monkeys $(20 \%)$ in group 3 
the number of dysenteric cases produced and serum agglutinin titers

\begin{tabular}{cccc}
\hline $\begin{array}{c}\text { No. of } \\
\text { dysenteric cases }\end{array}$ & $\begin{array}{c}\text { Average } \\
\text { incubation period } \\
\text { (days) }\end{array}$ & \multicolumn{2}{c}{ Average serum agglutinin titer* } \\
\cline { 3 - 4 } & 3 & $\begin{array}{c}\text { Before } \\
\text { challenge }\end{array}$ & $\begin{array}{c}2 \text { weeks } \\
\text { postchallenge }\end{array}$ \\
\hline 3 & 4.3 & 3.4 & 5.3 \\
3 & 7.3 & 3.5 & 5.9 \\
0 & & 3.4 & 4.1 \\
\hline
\end{tabular}

were found positive for $S$. flexneri 2a on the 8th day after the administration with diarrheal materials, and, thereafter, 2 of 10 monkeys $(20 \%)$ in group 1 , 3 of 13 monkeys (23.1\%) in group 2 and 3 of 14 monkeys (21.4\%) in group 3 gave positive results for $S$. flexneri 2 a isolation from stools on the 15 th day after the administration, while from all of the 4 monkeys in group 4 no Shigella bacilli

Table 2. Summary of clinical, pathological and bacteriological findings in monkeys autopsied

\begin{tabular}{|c|c|c|c|c|c|c|c|c|c|}
\hline \multirow{2}{*}{ Group } & \multirow{2}{*}{$\underset{\text { No. }}{\text { Animal }}$} & \multirow{2}{*}{$\begin{array}{l}\text { Appear- } \\
\text { ance of } \\
\text { clinical } \\
\text { sign* } \\
\text { (days } \\
\text { after the } \\
\text { challenge) }\end{array}$} & \multirow{2}{*}{$\begin{array}{c}\text { Fate** } \\
\text { (days } \\
\text { after } \\
\text { the } \\
\text { chal- } \\
\text { lenge) }\end{array}$} & \multicolumn{2}{|c|}{$\begin{array}{l}\text { Large-intestinal } \\
\text { lesions }\end{array}$} & \multicolumn{4}{|c|}{$\begin{array}{l}\text { Isolation of } S \text {. flexneri 2a } \\
\text { from the gastrointestinal } \\
\text { tract**** }\end{array}$} \\
\hline & & & & $\begin{array}{cr}\text { Inten- } \\
\text { sity } \\
\\
n e r\end{array}$ & $\begin{array}{l}\text { Penetra- } \\
\text { tion of } \\
S . \text { flex- } \\
\text { eri } 2 \mathrm{a}^{* * *}\end{array}$ & $\begin{array}{l}\text { Lower } \\
\text { small } \\
\text { intes- } \\
\text { tine }\end{array}$ & Cecum & Colon & Rectum \\
\hline \multirow{2}{*}{1} & 3 & $\mathrm{P}(4)$ & S (8) & Slight & \pm & + & & - & + \\
\hline & 4 & $\mathrm{P}(3)$ & $\mathrm{D}(5)$ & Severe & H & + & & 9.6 & 9.3 \\
\hline \multirow{3}{*}{2} & 2 & $\mathrm{P}(4)$ & S (8) & Moderate & $\mathrm{e}+$ & - & & + & + \\
\hline & $6^{(1)}$ & $\mathrm{N}$ & $\mathrm{D}(9)$ & Moderate & e - & - & - & - & - \\
\hline & 16 & $\mathrm{P}(5)$ & $\mathrm{S}(7)$ & Severe & \# & & 7.8 & & 8.3 \\
\hline \multirow{3}{*}{3} & 2 & $\mathrm{P}(4)$ & $\mathrm{D}(5)$ & Severe & H & + & & 9.6 & 9.3 \\
\hline & 8 & $\mathrm{~N}$ & $\mathrm{~S}(21)$ & None & - & - & - & - & - \\
\hline & 9 & $\mathrm{P}(9)$ & S (10) & Severe & \# & + & & 6.7 & 7.3 \\
\hline
\end{tabular}

* P : Positive (bloody mucous stool), N: Negative.

** D : Died, S: Sacrificed.

*** H: Widely penetrated into the epithelial lining and lamina propria, +: Penetrated into the surface epithelium, not into the deeper crypt, 土: A few epithelial cells harbored $S$. flexneri 2a, - : No penetration.

**** Number of $S$. Alexneri 2a isolated per gram of intestinal content is expressed as logarithm to the base of 10 . $+: S$. flexneri 2a positive, - : S. flexneri 2a negative.

(1) The monkey died of muddy mucous diarrhea 9 days after the administration, a moderate catarrhalic colitis was observed in the large intestine from where $S$. dysenteriae 2 was isolated in number of $10^{7.9}$. 
were isolated throughout the observation period of 21 days.

Serum agglutinin titers in almost all monkeys of groups 1 and 2 showed a trend of two- or fourfold rise 1-2 weeks after the administration, but the titer rises of the other 2 groups were only twofold or less after 2 weeks (Table 1). These trends of antibody titer rise were noted regardless of the presence or absence of dysentery symptoms.

Table 2 summarizes gross and histological findings, including both the detection of fluorescing bacilli and the isolations of bacilli from various parts of the gastrointestinal tract of the animals autopsied 5-21 days after the administration. In all of the dysenteric cases, no pathologic change was observed in the stomach and the small intestine, while various degree of inflammatory reaction and bacterial penetration were observed in the large intestine without exception. For example, in a dysenteric case No. 3 of group 1 autopsied 8 days after the administration when the stool property returned back to normal, only microfoci containing fluorescing bacilli in epithelial cells of the limited areas were observed in the rectum, and also inflammatory response was limited to the lamina propria just under the parasitized epithelia.

Four monkeys (No. 4 of group 1, No. 16 of group 2, and Nos. 2, 9 of group 3) autopsied 1-2 days after the onset of dysentery showed severe changes, that is, the hyperemia, hemorrhage, oedema, and erosion of the mucous membrane were observed on the extensive areas of the large intestine, and $S$. flexneri $2 \mathrm{a}$ penetrated into the deeper crypt and the lamina propria. These findings were almost the same as those in the infection of a freshly isolated $S$. flexneri 2a of frevious studies (Ogawa et al., 1964, 1966). In No. 6 of group 2 that died of muddy mucous diarrhea after 9 days, a moderate catarrhalic colitis was observed in the large intestine from where $S$. dysenteriae 2 was isolated, although no penetration of $S$. flexneri 2a into the epithelium of the catarrhalic areas was observed as well as negative cultures of $S$. flexneri 2 a from various parts of the gastrointestinal tract were obtained. It can be considered, therefore, that the development of a mild form of dysentery was caused by naturally infected $S$. dysenteriae 2 .

In short, the present study demonstrates that, when a relatively small amount of fresh dysenteric contents of the colon of monkeys was orally administered, dysentery with the same clinical and pathological findings as those in the oral challenge with a dose of freshly isolated $S$. flexneri 2 a as large as $10^{9}-10^{10}$ could be produced.

On the basis of the present results, we consider that the following three possibilities must be elucidated in further studies with regard to the virulence of Shigella bacilli: (1) the virulence of Shigella bacilli being present in fresh dysenteric contents of the colon is essentially higher for monkeys than that of Shigella bacilli freshly isolated from dysenteric contents on a culture medium, (2) some substances in fresh dysenteric contents enhance the infectivity of Shigella bacilli, and (3) some substances in fresh dysenteric contents inhibit the decline of the virulence.

Recently, Nakamura et al. (1966) and Nakamura (1967) showed that a loss of virulence of Shigella bacilli during cultivation on culture media resulted from reduction in the ratio of the number of virulent bacilli to the total bacilli grown, by employing such a test system as keratoconjunctival infection in guinea pigs 
and infection of cell cultures with Shigella. Thus, this fact also seems worthwhile to be taken into consideration when our present results are discussed, regarding the virulence of Shigella, that is, the dysenteric contents administered in the present experiment may have contained virulent bacilli exceeding in number the suspension of freshly isolated bacilli used in our previous experiment.

Furthermore, the present experiment may suggest that the ingestion of at least $10^{4}-10^{5}$ (about $0.1-10 \mathrm{mg}$ in terms of the amount of fresh dysenteric stool) Shigella bacilli is necessary for the establishment of infection in naturally occurring dysentery of monkeys.

\section{REFERENCES}

Honjo, S., Takasaka, M., Fujiwara, T., Nakagawa, M., Ando, K., Ogawa, H., TakaHASHI, R. AND IMAIZUMI, K. (1964): Shigellosis in cynomolgus monkeys (Macaca irus). II. Experimental infection with Shigella flexneri 2a with special references to clinical and bacteriological findings. Japan. J. Med. Sci. Biol., 17, 307-319.

Honjo, S., Takasaka, M., Fujiwara, T., Kaneko, M., Imaizumi, K., Ogawa, H., Mise, K., NAKAMURA, A. AND NAKAYA, R. (1967): Shigellosis in cynomolgus monkeys (Macaca irus). V. Resistance acquired by the repetition of experimental oral infection with Shigella flexneri 2a and fluctuation of serum agglutinin titer. Japan. J. Med. Sci. Biol., 20, 341-348.

Honjo, S., Takasaka, M., Imaizumi, K., Ogawa, H. ANd Nakaya, R. (1968): Oral challenge with Shigella flexneri $2 \mathrm{a}$ in cynomolgus monkeys having extremely high titer of serum agglutinin. Japan. J. Med. Sci. Biol., 21, 283-287.

Honjo, S., Takasaka, M., Fujiwara, T., Imaizumi, K. and Ogawa, H. (1969): Shigellosis in cynomolgus monkeys (Macaca irus). VII. Experimental production of dysentery with a relatively small dose of Shigella flexneri $2 \mathrm{a}$ in ascorbic acid deficient monkeys. Japan. J. Med. Sci. Biol., 22, 149-162.

Nakamura, A., Nakaya, R., Mise, K., Ogawa, H. And Yoshikura, H. (1966): Variation of virulence of Shigella strains during maintenance on artificial media. Japan. J. Bacteriol., 21, 425-426. (in Japanese)

NAKAMURA, A. (1967): Virulence of Shigella. Biological Sci., 19, 73-77. (text in Japanese)

Ogawa, H., Takahashi, R., Honjo, S., Takasaka, M., Fujiwara, T., Ando, K., NAKAGawa, M., Muto, T. AND Imaizumi, K. (1964): Shigellosis in cynomolgus monkeys (Macaca irus). III. Histopathological studies on natural and experimental shigellosis. Japan. J. Med. Sci. Biol., 17, 321-332.

Ogawa, H., Honjo, S., Takasaka, M., Fujiwara, T. and Imaizumi, K. (1966): Shigellosis in cynomolgus monkeys (Macaca irus). IV. Bacteriological and histopathological observations on the earlier stage of experimental infection with Shigella flexneri 2a. Japan. J. Med. Sci. Biol., 19, 23-32.

Ogawa, H., Nakamura, A., Nakaya, R., Mise, K., Honjo, S., Takasaka, M., FujiWARA, T. AND IMAIZUMI, K. (1967): Virulence and epithelial cell invasiveness of dysentery bacilli. Japan. J. Med. Sci. Biol., 20, 315-328.

Takasaka, M., Honjo, S., Fujiwara, T., Imaizumi, K. And Ogawa, H. (1967): Experimental infection with small doses of virulent Shigella flexneri 2a in cynomolgus monkeys (Macaca irus). Clinical and bacteriological observations. Japan. J. Med. Sci. Biol., 20, 195-198.

Takasaka, M., Honjo, S., Fujiwara, T., Imaizumi, K., Ogawa, H., Nakaya, R. AND NAKAMURA, A. (1968): Shigellosis in cynomolgus monkeys (Macaca irus). VI. The inoculation with various doses of Shigella flexneri 2a into cecal lumen. Japan. J. Med. Sci. Biol., 21, 275-281. 
Department of Veterinary Science, National Institute of Health,

Department of Pathology, National Institute of Health, Shinagawa-ku Tokyo 141, Japan

Received: July 27, 1970
MASAO TAKASAKA SHIGEO HONJO KIYOSHI IMAIZUMI

HIDEMASA OGAWA*

* Present adress: Biological Research Laboratory, Research Laboratories, DAIICHI SEIYAKU Co., Ltd. 2810, Minami-Funabori-cho Edogawa-ku, Tokyo, Japan.

高阪精夫 - 本庄重男 - 今泉清 (国立予防衛生研究所獣度部)

小河秀正（国立予防衛生研究所病理部；現第一製薬株式会社綜合研究所） 